\title{
A comparison of effectiveness of hepatitis $B$ screening and linkage to care among foreign-born populations in clinical and nonclinical settings
}

This article was published in the following Dove Press journal:

Journal of Multidisciplinary Healthcare

6 January 2015

Number of times this article has been viewed

\author{
Edwin Chandrasekar ${ }^{\prime}$ \\ Ravneet Kaur ${ }^{\prime}$ \\ Sharon Song' \\ Karen E Kim²
}

'Asian Health Coalition, Chicago, IL, USA; ${ }^{2}$ Division of the Biological Sciences and Office of Community Engagement and Cancer Disparities, University of Chicago, Chicago, IL, USA
Correspondence: Edwin Chandrasekar Asian Health Coalition, 180 West Washington Street, Office 1000,

Chicago, IL 60602, USA

Tel + I 3|2 73| 8634

Email edwin@asianhealth.org
Abstract: Hepatitis B (HBV) is an urgent, unmet public health issue that affects Asian Americans disproportionately. Of the estimated 1.2 million living with chronic hepatitis B in USA, more than $50 \%$ are of Asian ethnicity, despite the fact that Asian Americans constitute less than $6 \%$ of the total US population. The Centers for Disease Control and Prevention recommends HBV screening of persons who are at high risk for the disease. Yet, large numbers of Asian Americans have not been diagnosed or tested, in large part because of perceived cultural and linguistic barriers. Primary care physicians are at the front line of the US health care system, and are in a position to identify individuals and families at risk. Clinical settings integrated into Asian American communities, where physicians are on staff and wellness care is emphasized, can provide testing for HBV. In this study, the Asian Health Coalition and its community partners conducted HBV screenings and follow-up linkage to care in both clinical and nonclinical settings. The nonclinic settings included health fair events organized by churches and social services agencies, and were able to reach large numbers of individuals. Twice as many Asian Americans were screened in nonclinical settings than in health clinics. Chi-square and independent samples $t$-test showed that participants from the two settings did not differ in test positivity, sex, insurance status, years of residence in USA, or education. Additionally, the same proportion of individuals found to be infected in the two groups underwent successful linkage to care. Nonclinical settings were as effective as clinical settings in screening for HBV, as well as in making treatment options available to those who tested positive; demographic factors did not confound the similarities. Further research is needed to evaluate if linkage to care can be accomplished equally efficiently on a larger scale.

Keywords: community-based settings, public health, health disparities, disease management

\section{Introduction}

Hepatitis B (HBV) is a life-threatening viral infection that leads to acute and chronic liver diseases ${ }^{1}$ including cancer and cirrhosis. ${ }^{2}$ Worldwide, it is estimated that about 350 million people are infected, ${ }^{3,4}$ and nearly 1 million lose their lives annually due to HBV infection and its complications. ${ }^{5}$ The burden of the disease is not homogenous throughout the population. It disproportionately affects people from Asian countries. In Asia, the proportion of liver cancer deaths is higher from HBV than from the hepatitis $\mathrm{C}$ virus, aflatoxins, alcoholism, and smoking. ${ }^{6}$

In the United States, Asian Americans are the fastest growing minority group. There are nearly 18.2 million Asian Americans nationwide representing $5.6 \%$ of the total population, and estimates show this number will reach 40 million by $2050{ }^{7}$ More than $65 \%$ are foreign-born immigrants and refugees who come from low-income, 
limited-English-proficient backgrounds. ${ }^{8}$ On a local level, the Chicago, IL metropolitan area has the largest concentration of Asian Americans in the Midwest and fifth largest in the nation, totaling nearly 550,000 individuals. ${ }^{9}$

In USA, the number of individuals infected with HBV is approximately 1.2 million. ${ }^{3}$ Recent studies estimate this number to be as high as 2 million, and Asian Americans account for more than $50 \%$ of people living with chronic HBV even though they constitute less than $6 \%$ of the total US population. ${ }^{10}$ Among Asian Americans with HBV infection, fewer than $25 \%$ have been diagnosed, and 40\%-65\% have not been tested. ${ }^{11}$ Primary care physicians in clinical settings are often the point of entry into the US health care system and can identify individuals and families at risk for HBV as well as provide screening and follow-up care. Unfortunately, Asian Americans often do not feel understood by or confident in their doctors, participate in decision-making, or seek preventive health services. ${ }^{12}$ Furthermore, physicians may not know or may underestimate HBV risk factors ${ }^{13}$ and may not screen immigrants from $\mathrm{HBV}$-endemic areas nor those who have household contact with HBV-infected persons. ${ }^{14}$

Improving the identification and public health management of persons entering or living in USA who have chronic HBV infection is critical to eliminating transmission of the virus and reducing the incidence of HBV-related liver diseases. ${ }^{15}$ A landmark report published by the Institute of Medicine highlighted viral hepatitis as an urgent, unmet medical need and recommended new policy, community, and health care-based efforts to control HBV infection. ${ }^{15}$ Since 1988, policies have recommended prenatal HBV testing of all pregnant women, but, until May 2014, mechanisms to fund and track screening of other adults, including persons from highly endemic countries, were not supported. Therefore, in underserved Asian American immigrant and refugee communities, where HBV positivity rates can approach $10 \%-12 \%$, many community-based programs have been developed to screen members for HBV in nonclinical and clinical settings. ${ }^{16-18}$

\section{Nonclinical settings}

Viral HBV screenings can be conducted in different nonclinical venues such as health fairs and other events hosted by community- and faith-based organizations. Asian Americans seeking care from providers who speak their language receive more health education than those without same-language health care providers. ${ }^{19} \mathrm{Cultural}$ barriers perpetuating denial and social stigma, concerns about the costs of treatment if tested positive, limited English proficiency, and the absence of an English-speaking household member are some of the reasons foreign-born Asian Americans often prefer preventive screenings in nonclinical settings. ${ }^{20}$

Health fairs are the most recognizable form of community screenings and are common for disseminating information about HBV, diabetes, high cholesterol, and depression. ${ }^{21-25}$ They can be effective for identifying and screening at-risk populations. ${ }^{26,27}$ Many community-based organizations in Asian American communities have conducted screening activities to identify foreign-born persons with chronic HBV infection. Woo et $\mathrm{al}^{28}$ found that culturally and linguistically tailored programs were required to motivate patient and provider involvement. Non-health-related entities such as local community churches also effectively promote participation and increase the number of individuals who undergo screening. ${ }^{29}$

\section{Clinical settings}

Clinical settings include community health centers, federally qualified health centers, free or charitable clinics, solo and small group physician practices, and hospitals. The sites are staffed with primary care physicians and offer preventive health care at a high volume. Yet, in a study of primary care providers treating Asian Americans, only $36 \%$ of respondents reported routinely screening for $\mathrm{HBV} .{ }^{13}$ Screening rates were lowest with providers in the Chicago and Houston, TX metropolitan areas. ${ }^{13}$ Work schedules, financial constraints, limited provider knowledge, language barriers, cultural differences, and inadequate insurance were barriers. ${ }^{13,18,30}$

\section{Linkage to care}

Although health screenings in nonclinical settings have the ability to reach large segments of the public who are at risk for $\mathrm{HBV}$, data on the process of service delivery, follow-up treatment, and health outcomes are lacking. No systematic study has compared clinical to nonclinical settings, and the linkage to care component of those found to be infected has not been evaluated. Linkage to care is the process of directing individuals diagnosed with chronic hepatitis infection into medical care, where the levels of assistance vary according to need. Existing studies primarily calculated prevalence rates or identified factors associated with HBV screening and vaccination behaviors. Currently, there is not an infrastructure connecting community-based screenings for HBV to appropriate follow-up treatment. Nonclinical settings can facilitate outreach to large numbers, and can accommodate linkage to care much like clinical settings. Using nonclinical settings to increase the number of infected individuals who 
complete the necessary medication regimen fills a public health gap and can substantially reduce the disease burden. The aim of this study was to demonstrate the comparability of screening participation and follow-up linkage to care for the chronically infected in clinical and nonclinical settings.

\section{Methods}

\section{Asian Health Coalition}

The Asian Health Coalition (AHC) is a nonprofit organization whose mission is to improve the health and well-being of Asian Americans and Pacific Islanders in Illinois through advocacy, technical assistance, education, and community-based research. It partners with different ethnic communities to build sustainable health promotion programs in the metropolitan Chicago area. The AHC directed the project and saw to it that staffing and program resources were appropriately distributed.

\section{HEPP model linkage to care}

The Hepatitis Education and Prevention Program (HEPP) was developed by the AHC in collaboration with multiple stakeholders, including academic and community partners. It provides evidence-based education to immigrant and refugee populations at high risk for HBV and liver cancer. The HEPP is distinguished for its partnerships with physician providers who are key to reliable and sustainable linkage to care opportunities. It uses a community health worker model to minimize the challenges of illiteracy, limited language access, and distrust, and respects Health Insurance Portability and Accountability Act guidelines.

\section{Screenings and lab results}

The test results were sent by Quest Diagnostics to the HEPP program manager, who made an aggregate record of the findings and a copy of each individual lab result. Copies were mailed to participants along with a notification letter in English and the participant's native language. The notification letter classified test results into one of three categories:

1. Immune: the individual was found to be immune to $\mathrm{HBV}$ and required no further follow-up.

2. Susceptible: the individual did not have immunity, had not been vaccinated, and was susceptible to HBV exposure. A recommendation to undergo the three-series vaccination was made.

3. Infected: the individual was chronically infected with HBV and was provided with instructions for seeking medical attention. The notification letter offered the name and contact phone number of a staff member from the partnering community-based organization prepared to make referrals. With guidance from the HEPP program manager, the staff liaison helped clients make appointments with local health care providers based on individual health insurance coverage.

\section{Screening sites}

Viral HBV screenings were conducted at three clinical and ten nonclinical settings in 13 different locations throughout the metropolitan Chicago area, from December 2012 to December 2013. The settings were identified based on community partners who collaborated with AHC on previous health promotion programs. They serve a majority of foreign-born, low-income immigrants, and refugees from Asian and African countries. See Table 1 for the screening sites and participant counts.

In the clinical settings, the $\mathrm{AHC}$ worked with the respective administrative staff to develop a protocol for identifying foreign-born patients from Asia and Africa as they came

Table I Screening sites and participant counts

\begin{tabular}{|c|c|c|c|c|}
\hline Site type & Name of screening site & Designation & Frequency (n) & Percent \\
\hline \multirow[t]{3}{*}{ Clinical settings } & Asian Human Services & FQHC & 53 & 7.0 \\
\hline & Heartland Health Centers & FQHC & 101 & 13.3 \\
\hline & Korean American Family Clinic & $\mathrm{CHC}$ & 75 & 9.9 \\
\hline \multirow[t]{10}{*}{ Nonclinical settings } & Quang Minh Viet Temple & $\mathrm{FBO}$ & 43 & 5.7 \\
\hline & African United Community Methodist Church & FBO & 39 & 5.1 \\
\hline & Cambodian Association of Illinois & CBO & 28 & 3.7 \\
\hline & Chinese American Service League & CBO & 57 & 7.5 \\
\hline & Chicago Mongolian Mission Church & $\mathrm{FBO}$ & 43 & 5.7 \\
\hline & Ethiopian Community Association of Chicago & CBO & 44 & 5.8 \\
\hline & Filipino Community Health Fair & Health fair & 42 & 5.5 \\
\hline & Hanul Family Alliance & СBO & 48 & 6.3 \\
\hline & Lao American Organization of Elgin & CBO & 144 & 19.0 \\
\hline & Tibetan Alliance of Chicago & CBO & 41 & 5.4 \\
\hline Totals & & & 758 & 100 \\
\hline
\end{tabular}

Abbreviations: $\mathrm{CBO}$, community-based organization; $\mathrm{CHC}$, community health clinic; FBO, faith-based organization; FQHC, federally qualified health center. 
in for office visits. Physicians provided brief education on HBV during the consultation and offered a free screening. Consent for the blood draw was obtained and a brief, selfadministered patient survey questionnaire (PSQ) collecting demographic and risk factor data was administered. Results of the screenings were provided directly to the patient, and also reported to the AHC.

Screenings in the nonclinical settings were held in conjunction with an education session on HBV delivered either in the target language of the community or with interpretation using bilingual community health workers trained by $\mathrm{AHC}$ staff in the HEPP model. Participants were offered free HBV screenings after the education sessions. Bilingual volunteers assisted participants with the consent forms, and volunteer nurses and phlebotomists performed the blood draws that were forwarded directly to Quest Diagnostics (contracted with the AHC). Test results were provided to the AHC, who reviewed them and prepared notification forms, translated into the target languages spoken in the communities, that were mailed to participants.

All participants were tested for the HBV surface antigen (HBsAg), core antibody (anti-HBc), and surface antibody (anti-HBs). For individuals who were uninsured or did not have a provider, the notification letter included contact information of the AHC program manager and/or bilingual community health worker so they could make the necessary linkage to care.

\section{Data collection and analysis}

Results from the PSQ and clinical test results were analyzed using SPSS software (v 21; IBM Corporation, Armonk, NY, USA). Chi-square and independent samples $t$-test evaluated whether or not Asian Americans who obtained HBV screenings in clinical settings differed significantly from those in nonclinical settings. The independent variables were HBsAg test result, sex, English language preference, insurance availability, years residing in USA, and education. Chi-square tests of independence were also used to examine the associations of $\mathrm{HBV}$ risk factors to $\mathrm{HBsAg}$ test results.

\section{Results}

As shown in Table 1, a total of 758 screenings occurred at 13 different organizations, with $n_{c s}=229$ and $n_{n c s}=529$. More than $94 \%$ of participants were born in Asia and Africa; the majority were born in South, East, and Southeast Asia, with $10.8 \%$ having migrated from Africa. About $27.5 \%$ of participants had been living in USA for less than 20 years.
More than one-half screened did not have insurance $(52.8 \%)$, and $32.5 \%$ did not see a regular doctor. See Table 2 for the sample distributions by site type, sex, race, age, country of origin, years in USA, insurance status, physician involvement, and language preference.

Figure 1 presents the risk factors associated with HBV infection and their frequencies. Most behaviors were not

Table 2 Description of sample

\begin{tabular}{|c|c|c|}
\hline Variable & $\begin{array}{l}\text { Total number } \\
\left(n_{T}=758\right)\end{array}$ & Percentage \\
\hline \multicolumn{3}{|l|}{ Site type } \\
\hline Clinical settings & 229 & 30.2 \\
\hline Nonclinical settings & 529 & 69.8 \\
\hline \multicolumn{3}{|l|}{ Sex } \\
\hline Male & 285 & 37.6 \\
\hline Female & 470 & 62.0 \\
\hline Not indicated & 3 & 0.4 \\
\hline \multicolumn{3}{|l|}{ Race } \\
\hline Asian & 620 & 81.8 \\
\hline Other & 93 & 12.2 \\
\hline Not indicated & 45 & 5.9 \\
\hline \multicolumn{3}{|l|}{ Age } \\
\hline Less than 30 years & 67 & 8.8 \\
\hline $30-39$ years & 104 & 13.7 \\
\hline $40-49$ years & 186 & 24.5 \\
\hline $50-59$ years & 181 & 23.9 \\
\hline $60-69$ years & 169 & 22.3 \\
\hline 70 years or older & 50 & 6.6 \\
\hline Not indicated & I & 0.1 \\
\hline \multicolumn{3}{|l|}{ Region of birth } \\
\hline South Asia & 100 & 13.2 \\
\hline East Asia & 235 & 31.0 \\
\hline Southeast Asia & 289 & 38.1 \\
\hline Africa & 82 & 10.8 \\
\hline North America & 7 & 0.9 \\
\hline Europe & I & 0.1 \\
\hline Not indicated & 44 & 5.8 \\
\hline \multicolumn{3}{|l|}{ Residence years } \\
\hline \multicolumn{3}{|c|}{ in the United States } \\
\hline Less than 10 years & 108 & 14.2 \\
\hline $10-19$ years & 101 & 13.3 \\
\hline $20-29$ years & 78 & 10.3 \\
\hline 30 or more years & 120 & 15.8 \\
\hline Not indicated & 351 & 46.3 \\
\hline \multicolumn{3}{|l|}{ Insurance status } \\
\hline Yes & 271 & 35.8 \\
\hline No & 400 & 52.8 \\
\hline Not indicated & 87 & 11.5 \\
\hline \multicolumn{3}{|c|}{ Registered doctor or } \\
\hline \multicolumn{3}{|c|}{ health care provider } \\
\hline Yes & 169 & 22.3 \\
\hline No & 246 & 32.5 \\
\hline & 343 & 45.3 \\
\hline \multicolumn{3}{|l|}{ English as primary } \\
\hline \multicolumn{3}{|l|}{ language } \\
\hline Yes & 74 & 9.8 \\
\hline No & 684 & 90.2 \\
\hline
\end{tabular}




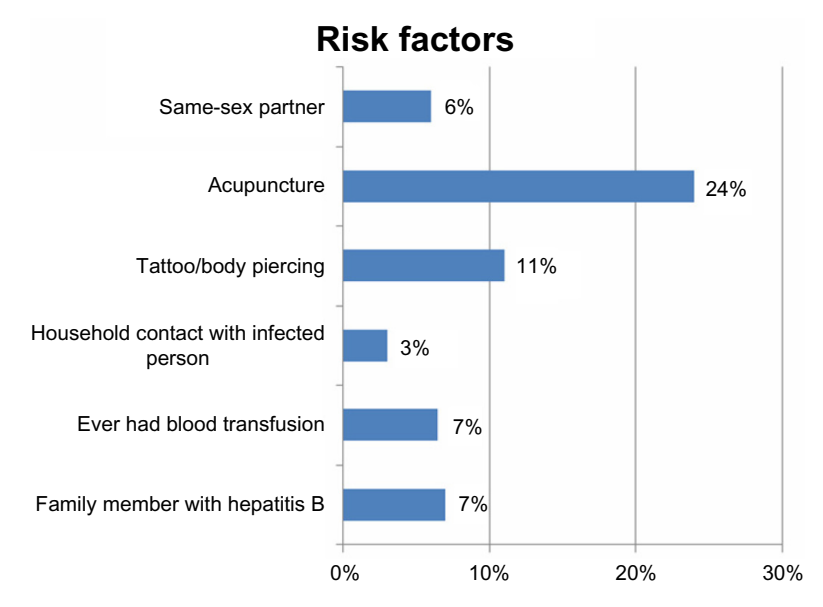

Figure I Risk factors associated with hepatitis B infection.

endorsed by participants. The highest occurring activity was the use of acupuncture, but approximately three-fourths reported not engaging in it.

\section{$\mathrm{HBsAg}$ prevalence}

The overall prevalence for HBsAg positivity in the sample was $7.3 \%(\mathrm{n}=55)$, which was comparable to the Centers for Disease Control and Prevention (CDC)'s prevalence rate of 8\% among Asian Americans. ${ }^{3}$ After stratifying respondents according to type of screening site, the prevalence for HBsAg positivity was $7.4 \%$ in nonclinical settings and $7.0 \%$ in their clinical counterpart. There was not a significant association between test result and screening site type $\left(\chi^{2}=0.02, \mathrm{df}=1\right.$, $\left.P>0.05, \Phi_{\mathrm{C}}=0.005\right)$. Individuals who ended up testing positive for the disease were as likely to participate in clinical as in nonclinical settings. Table 3 lists the nine highest infection rates by country of birth. The prevalence for HBsAg positivity was highest $(>8.0 \%)$ among people born in Laos, People's Republic of China, and Cambodia.

Table 3 Hepatitis B infection rate by country of origin

\begin{tabular}{llll}
\hline Country of origin & \multicolumn{3}{l}{ HBsAg positivity } \\
\cline { 2 - 4 } & $\begin{array}{l}\text { Nonclinical } \\
\text { settings }\end{array}$ & $\begin{array}{l}\text { Clinical } \\
\text { settings }\end{array}$ & Totals \\
\hline Laos & 14 & $\mathrm{I}$ & 15 \\
Korea & 2 & 2 & 4 \\
Philippines & $\mathrm{I}$ & 2 & 3 \\
Vietnam & 2 & 0 & 2 \\
People's Republic of China & 7 & $\mathrm{I}$ & 8 \\
Cambodia & 4 & 0 & 4 \\
Ghana & 2 & 0 & 2 \\
Nepal & $\mathrm{I}$ & $\mathrm{I}$ & 2 \\
Bhutan & 0 & $\mathrm{I}$ & 1 \\
Others & 6 & 10 & 16 \\
Overall prevalence & $7.4 \%$ & $7.0 \%$ & $7.3 \%$ \\
\hline Abbreviaton: &
\end{tabular}

Abbreviation: $\mathrm{HBsAg}$, hepatitis $\mathrm{B}$ surface antigen.

\section{Comparisons between clinical and nonclinical settings}

There were no significant associations between type of screening site and sex, English language preference, insurance availability, years residing in USA, or education. Similar to HBsAg findings, men and women were not more or less inclined to attend screening events based on where they were held. In the clinical settings, the distribution of males to females was $36.2 \%$ to $63.8 \%$. In the nonclinical arenas, it was $38.0 \%$ to $62 \%$. These proportions were not significantly different from the general population $\left(\chi^{2}=0.215, \mathrm{df}=1, P>0.05, \Phi_{\mathrm{C}}=0.017\right)$.

In the entire sample, a total of $81.2 \%$ did not speak English as their primary language. The difference to those who were fluent in the English language was statistically significant, but the nearly 4:1 ratio observed in the total sample was similar to the clinical and nonclinical subsamples, indicating that language and type of setting were independent of each other $\left(\chi^{2}=13.301, \mathrm{df}=1, P<0.01, \Phi_{\mathrm{C}}=0.017\right)$. Since the target population was foreign-born Asian Americans, the large volume of non-English speaking participants was expected.

A similar pattern was found when examining the relationship between insurance status and type of setting. In the overall sample, a total of $60.3 \%$ did not have insurance coverage. The difference to those who were insured was statistically significant, but the nearly $3: 1$ ratio observed in the total sample was similar to the clinical and nonclinical subsamples, indicating that availability of insurance and type of setting were independent of each other $\left(\chi^{2}=8.818, \mathrm{df}=1\right.$, $\left.P<0.01, \Phi_{\mathrm{C}}=0.115\right)$. The disproportionately higher number of participants without insurance was to be expected.

To evaluate whether or not there was a difference between the number of years participants lived in USA and screening settings, a two-tailed independent samples $t$-test was calculated with type of setting as the dependent variable and years living in USA measured continuously as the independent variable. Length of residence in USA did not influence screening involvement in clinical over nonclinical settings, or vice versa $(t(72)=1.001, P>0.05)$.

In the entire sample, a total of $64.1 \%$ were educated at the high school level or beyond. The difference to those individuals with less education was statistically significant, but the nearly 2:1 ratio observed in the total sample was similar to the clinical and nonclinical subsamples, indicating that education and type of setting were independent of each other $\left(\chi^{2}=13.301, \mathrm{df}=1, P<0.01, \Phi_{\mathrm{C}}=0.017\right)$. The overall higher education of foreign-born Asian Americans was a characteristic for which discussion was beyond the scope of this study. 
Table 4 summarizes the degree of association between each of the risk factors and the HBV screening results. All relationships were weak (ie, $\Phi_{\mathrm{C}}<0.300$ ). Being with a same-sex partner, having household contact with an infected person, and experiencing acupuncture were significantly higher in "no" responses than "yes" (reflected in the large chi-squares and significant $P$-values). They were not associated with significant differences between "positive" and "negative" HBsAg screening results. These findings were consistent with the perceived lowered risk of HBV typically associated with Asian Americans that might explain why they are often not identified as in need of screening.

\section{Linkage to care}

Linkage to care was provided to individuals who were positive for HBsAg. The first step was to provide posttest counseling to everyone found to be infected. In the clinical settings, of the 16 individuals who tested positive for $\mathrm{HBsAg}, 56 \%$ $(n=9)$ were referred to follow-up medical care to either a primary care physician or local provider facility. For those who were not referred, three individuals refused further medical care, and four could not be contacted despite additional attempts.

For those individuals tested in nonclinical settings, a brochure was mailed with the results, as well as information about HBV and its risk factors. The next step was a follow-up phone call from bilingual community health workers affiliated with the partnering agencies. They provided assistance and referrals to physicians for further treatment when needed. Referrals were made to different medical facilities based on insurance status. Of the 39 individuals who tested positive for HBsAg, 77\% $(n=30)$ were referred to medical care. Eleven were linked to a primary care physician and 19 individuals sought care at medical centers. The remaining individuals $(n=9)$ who were not

Table 4 Chi-square tests of independence between risk factors and $\mathrm{HBsAg}$ results

\begin{tabular}{lccl}
\hline Risk factor & \multicolumn{3}{l}{ HBsAg positivity } \\
\cline { 2 - 4 } & $\chi^{2}, \mathbf{d f}$ & P-value & $\boldsymbol{\Phi}_{\mathrm{c}}$ \\
\hline Same-sex partner & $12.759, \mathrm{I}$ & $0.000^{*}$ & 0.178 \\
Acupuncture & $4.737, \mathrm{I}$ & $0.030^{*}$ & 0.109 \\
Household contact with & $8.743, \mathrm{I}$ & $0.003^{*}$ & 0.265 \\
infected person(s) & & & \\
Blood transfusion & $0.544, \mathrm{I}$ & $0.46 \mathrm{I}$ & 0.037 \\
Tattoos/body piercings & $0.407, \mathrm{I}$ & 0.523 & 0.032 \\
Family member with hepatitis B & $0.394, \mathrm{I}$ & 0.530 & 0.037 \\
\hline
\end{tabular}

Note: *Significant $\chi^{2}$ explained by a disproportionately large number of individuals responding "no."

Abbreviation: $\mathrm{HBs} A g$, hepatitis B surface antigen. referred could not be contacted after several attempts by nonclinical-setting staff and community health workers. See Table 5 for a summary.

\section{Missing data}

Large numbers of participants did not report the years they had resided in USA $\left(\mathrm{n}_{\mathrm{m}}=351 ; 46.3 \%\right)$, whether or not they saw a primary physician $\left(\mathrm{n}_{\mathrm{m}}=343 ; 45.3 \%\right)$ or had health insurance $\left(\mathrm{n}_{\mathrm{m}}=87 ; 11.5 \%\right)$, or country of birth $\left(\mathrm{n}_{\mathrm{m}}=44\right.$; $5.8 \%$ ). Fear of reprisal because of too much information self-revealed and sensitivity to stigma often associated with HBV disease may have explained participants' response patterns. Additionally, we suspect that some communitybased organizations were less able than others to assist lowliterate participants, even when the PSQs were translated into their spoken languages.

\section{Discussion}

This study is the one of the few to examine HBV screening and linkage to care among foreign-born individuals in clinical and nonclinical settings. We found no significant associations between a number of demographic factors and type of screening site. HBV screenings for Asian Americans at nonclinical settings were valued equally to the clinical settings. Our findings showed that there were no significant differences. This outcome is consistent with our hypothesis that nonclinical settings have the capacity to reach a large segment of underserved foreign-born populations who tend to be uninsured and have limited English proficiency.

A significant finding was the successful linkage to care available in nonclinical settings as compared to clinical settings. This study demonstrated the merits of using a community-based model for linkage to care. The partnerships with community-based organizations, community health workers, and physician providers described in the HEPP model are a part of the success in connecting chronically infected individuals to follow-up treatment. Linkage to care, an important component of the HEPP model, provides opportunities to infected individuals to have access to culturally competent medical care, achieving a "win-win-win" situation for communities, public health organizations, and providers. Previous studies revealed that financial and language barriers as well as cultural differences influenced health care providers' recommendations for HBV screening. ${ }^{13,15}$ Through the HEPP model, collaborations were forged with culturally competent physician providers who were familiar with the needs of the targeted foreign-born populations and were able to effectively overcome the barriers. 
Table 5 Linkage to care

\begin{tabular}{|c|c|c|c|c|c|c|c|}
\hline \multirow[t]{3}{*}{ Type of setting } & \multirow[t]{3}{*}{$\begin{array}{l}\text { Number of } \mathrm{HBsAg} \\
\text { positive individuals }\end{array}$} & \multirow{2}{*}{\multicolumn{2}{|c|}{$\begin{array}{l}\text { Posttest } \\
\text { counseling } \\
\text { provided }\end{array}$}} & \multirow{2}{*}{\multicolumn{2}{|c|}{$\begin{array}{l}\text { Referred } \\
\text { to medical } \\
\text { care }\end{array}$}} & \multicolumn{2}{|c|}{$\begin{array}{l}\text { Source of care when referred to } \\
\text { medical care indicated }\end{array}$} \\
\hline & & & & & & \multirow[t]{2}{*}{ Primary care physician } & \multirow[t]{2}{*}{ Medical facility } \\
\hline & & $\mathbf{Y}$ & $\mathbf{N}$ & $\mathbf{Y}$ & $\mathbf{N}$ & & \\
\hline Clinical setting & 16 & 16 & 0 & 9 & 7 & 5 & 4 \\
\hline Nonclinical setting & 39 & 39 & 0 & 30 & 9 & 11 & 19 \\
\hline
\end{tabular}

Abbreviations: $\mathrm{N}$, no; $\mathrm{Y}$, yes.

Community health workers in nonclinical settings are also integral pillars for success in overcoming distrust among foreign-born underserved populations. ${ }^{31}$ Various studies have discussed the effectiveness they achieve in aiding with different health problems such as diabetes, case management, child health, and HIV. ${ }^{32,33}$ Community health workers trained as patient navigators have been shown to successfully implement culturally tailored programs and reduce health disparities in ethnically diverse populations. ${ }^{34}$

In Europe, a similar success rate was found using a community-based approach to reducing screening disparities among immigrant populations. ${ }^{35}$ Stornaiuolo et $\mathrm{al}^{36}$ examined the impact of proactive participant recruitment in an Italian community that was home to 5 million immigrants in 2012. They used the mobile unit of a health and family counseling center dedicated to providing HIV screenings to otherwise difficult-to-serve participants, and compared the results to those obtained in their outpatient health clinic alone. The number of HIV-positive individuals identified over a 6-year period was significantly higher using the mobile unit than without it. Of note was that their HBsAg positivity rate of $7.6 \%$ was similar to ours.

Two methodological limitations in our study will be mentioned. First, the variables collected were categorical. In the future, use of continuous measures will make it possible to evaluate parametric procedures known to be more statistically powerful. The PSQ was selected for its ease of translation into multiple Asian languages, as well as its accommodation of low functional literate and limited-English-proficient participants. Second, the community partners who conducted the screenings tended to vary in internal resources. The total sample was dependent on their ability to recruit participants. Likewise, the quality of the data collected depended on the way the community partners went about completing the screening protocol. Well-established Asian communities with multiple generations of families in USA have denser populations than the groups with historically lower rates of migration. Future studies will benefit from establishing recruitment processes that produce the appropriate stratification and that standardize the role of community health workers at screening events.

\section{Conclusion}

Recruiting foreign-born populations from Asia and Africa for HBV screenings is challenging. Factors such as lack of insurance, limited English proficiency, ineligibility for public assistance programs, cost of health services, lack of medical interpretation services, and legal documentation status act as barriers to access and utilization of health care services. ${ }^{37}$ This study provided novel findings. Community-based HBV screenings in nonclinical settings for foreign-born populations were similar in clinical settings in terms of recruitment, disease prevalence, and other demographic characteristics. It magnified the need for culturally competent communitydriven health promotion and prevention programs such as HEPP that have strong linkages to care. Linkage to care increases access to the health care system and can reduce the gap experienced by underserved foreign-born populations. These findings serve as evidence for future interventions that might maximize collaborations with clinical and nonclinical health care service providers. Further research is required to understand the strategies that best engage providers in community screenings with linkage to care arrangements, and accomplish the CDC's recommendations ${ }^{3}$ for appropriate HBV testing.

\section{Acknowledgments}

The education and screening activities in this study were made possible by the Centers for Disease Control and Prevention, Chicago Department of Public Health, Illinois Department of Public Health, and various private foundations. We also thank the following community-based organizations for their partnerships: African Community United Methodist Church, Cambodian Association of Illinois, Chinese American Service League, Ethiopian Community Association of Chicago, Heartland Health Centers, Korean American Community Services, Lao American Organization of Elgin, Mongolian Community Center, Vietnamese Association of Illinois, and other faith-based institutions assisting with the education, outreach, and recruitment of participants. We appreciate the University of Chicago's Institutional Review Board for providing ethical review on the project. 


\section{Disclosure}

The authors report no conflicts of interest in this work.

\section{References}

1. Hepatitis B [webpage on the Internet]. Geneva: World Health Organization [updated July 2014]. Available from: http://www.who. int/mediacentre/factsheets/fs204/en. Accessed September 22, 2014.

2. Fauci AS, Morens DM. The perpetual challenge of infectious diseases. N Engl J Med. 2012;366(5):454-461.

3. Viral Hepatitis Populations [webpage on the Internet]. Atlanta, GA: Centers for Disease Control and Prevention [updated March 21, 2014]. Available from: http://www.cdc.gov/hepatitis/populations/api.htm. Accessed September 22, 2014.

4. Perz JF, Armstrong GL, Farrington LA, Hutin YJ, Bell BP. The contributions of hepatitis B virus and hepatitis $\mathrm{C}$ virus infections to cirrhosis and primary liver cancer worldwide. J Hepatol. 2006;45(4):529-538.

5. Statistics [webpage on the Internet]. Doylestown, PA: Hepatitis B Foundation [updated February 19, 2014]. Available from: http://www. hepb.org/hepb/statistics.htm. Accessed September 22, 2014.

6. Fan JH, Wang JB, Jiang Y, et al. Attributable causes of liver cancer mortality and incidence in china. Asian Pac J Cancer Prev. 2013;14(12): $7251-7256$.

7. Le CN. 14 Important Statistics About Asian Americans [webpage on the Internet]. Asian-Nation; 2014. Available from: http://www.asiannation.org/14-statistics.shtml. Accessed September 22, 2014.

8. Asian American/Pacific Islander profile. US Department of Health and Human Services Office of Minority Health Resource Center. Available from: http://minorityhealth.hhs.gov/omh/browse.aspx?lvl=3\&lvlid=63. Accessed September 22, 2014.

9. American community survey. US Census Bureau. Available from: http:// www.census.gov/prod/2007pubs/acs-05.pdf. Accessed September 22, 2014.

10. Kowdley KV, Wang CC, Welch S, Roberts H, Brosgart CL. Prevalence of chronic hepatitis B among foreign-born persons living in the United States by country of origin. Hepatology. 2012;56(2):422-433.

11. Hutton DW, Tan D, So SK, Brandeau ML. Cost-effectiveness of screening and vaccinating Asian and Pacific Islander adults for hepatitis B. Ann Intern Med. 2007;147(7):460-469.

12. Collins KS, Hughes DL, Doty MM, Ives BL, Edwards JN, Tenney K. Diverse Communities, Common Concerns: Assessing Health Care Quality for Minority Americans. The Commonwealth Fund; 2002. Available from: http://www.commonwealthfund.org/ /media/files/ publications/fund-report $/ 2002 / \mathrm{mar} /$ diverse-communities--commonconcerns--assessing-health-care-quality-for-minority-americans/ collins_diversecommun_523-pdf.pdf. Accessed September 22, 2014.

13. Chu D, Yang JD, Lok AS, et al. Hepatitis B screening and vaccination practices in asian american primary care. Gut Liver. 2013;7(4): 450-457.

14. Bodle EE, Islam N, Kwon SC, Zojwalla N, Ahsan H, Senie RT. Cancer screening practices of Asian American physicians in New York City. J Immigr Minor Health. 2008;10(3):239-246.

15. Colvin HM, Mitchell AE, editors; Committee on the Prevention and Control of Viral Hepatitis Infections; Institute of Medicine. Hepatitis and Liver Cancer: A National Strategy for Prevention and Control of Hepatitis $B$ and $C$. Washington, DC: The National Academies Press; 2010.

16. Sarkar M, Stewart S, Yu A, Chen MS, Nguyen TT, Khalili M. Hepatocellular carcinoma screening practices and impact on survival among hepatitis B-infected Asian Americans. JViral Hepat. 2012;19(8):594-600.

17. Khalili M, Guy J, Yu A, et al. Hepatitis B and hepatocellular carcinoma screening among Asian Americans: survey of safety net healthcare providers. Dig Dis Sci. 2011;56(5):1516-1523.
18. Hwang JP, Mohseni M, Gor BJ, Wen S, Guerrero H, Vierling JM. Hepatitis B and hepatitis C prevalence and treatment referral among Asian Americans undergoing community-based hepatitis screening. Am J Public Health. 2010;100 Suppl 1:S118-S124.

19. Ngo-Metzger Q, Sorkin DH, Phillips RS, et al. Providing high-quality care for limited English proficient patients: the importance of language concordance and interpreter use. J Gen Intern Med. 2007;22 Suppl 2: 324-330.

20. Hu KQ. Hepatitis B virus (HBV) infection in Asian and Pacific Islander Americans (APIAs): how can we do better for this special population? Am J Gastroenterol. 2008;103(7):1824-1833.

21. Tabaei BP, Burke R, Constance A, et al. Community-based screening for diabetes in Michigan. Diabetes Care. 2003;26(3):668-670.

22. Bovet P, Hirsiger P, Emery F, et al. Impact and cost of a 2-week community-based screening and awareness program for diabetes and cardiovascular risk factors in a Swiss canton. Diabetes Metab Syndr Obes. 2011;4:213-223.

23. Holt RI, Abdelrahman T, Hirsch M, et al. The prevalence of undiagnosed metabolic abnormalities in people with serious mental illness. J Psychopharmacol. 2010;24(6):867-873.

24. Baker L, Oswalt K. Screening for postpartum depression in a rural community. Community Ment Health J. 2008;44(3):171-180.

25. Sullivan DR. Screening for cardiovascular disease with cholesterol. Clin Chim Acta. 2002;315(1-2):49-60.

26. Gish RG, Cooper SL. Hepatitis B in the Greater San Francisco Bay Area: an integrated programme to respond to a diverse local epidemic. J Viral Hepat. 2011;18(4):e40-e51.

27. Rein DB, Lesesne SB, Leese PJ, Weinbaum CM. Community-based hepatitis B screening programs in the United States in 2008. J Viral Hepat. 2010;17(1):28-33.

28. Woo GA, Hill MA, de Medina MD, Schiff ER. Screening for hepatitis B virus and hepatitis $\mathrm{C}$ virus at a community fair: a single-center experience. Gastroenterol Hepatol (N Y). 2013;9(5):293-299.

29. Bailey MB, Shiau R, Zola J, et al. San Francisco hep B free: a grassroots community coalition to prevent hepatitis B and liver cancer. J Community Health. 2011;36(4):538-551.

30. Ferrante JM, Winston DG, Chen PH, de la Torre AN. Family physicians' knowledge and screening of chronic hepatitis and liver cancer. Fam Med. 2008;40(5):345-351.

31. Brach C, Fraser I. Can cultural competency reduce racial and ethnic health disparities? A review and conceptual model. Med Care Res Rev. 2000;57 Suppl 1:181-217.

32. Volkmann K. Community Health Workers as Patient Navigators [webpage on the Internet]. Seattle, WA: Northwest Regional Primary Care Association. Available from: http://www.nwrpca.net/health-centernews/253-community-health-workers-as-patient-navigators.html. Accessed September 22, 2014.

33. Thompson JR, Horton C, Flores C. Advancing diabetes self-management in the Mexican American population: a community health worker model in a primary care setting. Diabetes Educ. 2007;33 Suppl 6: 159S-165S.

34. Percac-Lima S, Grant RW, Green AR, et al. A culturally tailored navigator program for colorectal cancer screening in a community health center: a randomized, controlled trial. J Gen Intern Med. 2009;24(2): 211-217.

35. Manesis EK. Immigration, European union and health issues: a commentary. Dig Liver Dis. 2014;46(1):25-26.

36. Stornaiuolo G, Cuniato V, Cuomo G, et al. Active recruitment strategy in disadvantaged immigrant populations improves the identification of human immunodeficiency but not of hepatitis B or C virus infections. Dig Liver Dis. 2014;46(1):62-66.

37. Cristancho S, Garces DM, Peters KE, Mueller BC. Listening to rural Hispanic immigrants in the Midwest: a community-based participatory assessment of major barriers to health care access and use. Qual Health Res. 2008;18(5):633-646. 
Journal of Multidisciplinary Healthcare

Dovepress

\section{Publish your work in this journal}

The Journal of Multidisciplinary Healthcare is an international, peerreviewed open-access journal that aims to represent and publish research in healthcare areas delivered by practitioners of different disciplines. This includes studies and reviews conducted by multidisciplinary teams as well as research which evaluates the results or conduct of such teams or healthcare processes in general. The journal covers a wide range of areas and welcomes submissions from practitioners at all levels, from all over the world. The manuscript management system is completely online and includes a very quick and fair peer-review system. Visit http://www.dovepress.com/testimonials.php to read real quotes from published authors.

Submit your manuscript here: http://www.dovepress.com/journal-of-multidisciplinary-healthcare-journal 